\title{
Impact of Game-Based and Think-Pair-Share Pedagogies on Teacher Trainees' Performance in Science
}

\author{
Joseph Parker
}

Department of Science Education, Enchi College of Education, Enchi, Ghana, West Africa,

\begin{abstract}
The purpose of the study was to determine the impact of game-based and think-pair-share pedagogies on teacher trainees' performance in science. This study adopted an action research design. The study was carried out in Enchi College of Education in the Western North Region of Ghana. Stratified, simple random and systematic sampling techniques were used to select 80 respondents ( 40 males and 40 females) for the study. The instrument used for the data collection was test. The findings of the study revealed that, the mean value of post-test and pre-test results of participants exposed to game-based pedagogy differ significantly. The findings of the study again revealed that, the mean value of post-test and pre-test results of participants exposed to think-pair-share pedagogy differ significantly. This implies that, the gamebased pedagogy and think-pair-share pedagogy had impact on teacher trainees' performance in science. It was therefore recommended that creative approaches such as game-based pedagogy and think-pair-share pedagogy should be adopted by science tutors in Enchi College of Education for effective teaching and learning of science.
\end{abstract}

Keywords: game-based, think-pair-share, pedagogy, strategy, creativity.

\section{Introduction}

Playing is one of learning principles of students in schools. Learning activity of children in schools should be managed with playing so that the children can be happy and comfortable. For children, playing is viewed as a natural activity in acquiring experiences, a tool to find creativity, and a facility to develop intelligence (Ismail, 2006). Think-pair-share approach on the other hand allows development of self-confidence and speaking skills among learners (Utama, Marhaeni \& Putra,2013). The purpose of this study was to examine the impact of game-based and think-pair-share pedagogies on teacher trainees' performance in science.

Based on the results and the discussions presented in relation to the hypothesis and research questions, It was realized from the testing of hypothesis that the mean score of 2.58 was obtained from the pre-test for teacher trainees exposed to game-based pedagogy whereas the mean score obtained for the post-test was 6.83 , a mean gain of 4.25 in favour of the post-test. The null hypothesis that there was no statistically significant difference between the pre-test scores and post-test scores when game-based pedagogy is used was therefore rejected at 0.05 significance level. It was again revealed that, the mean score of 2.10 was obtained from the pre-test for teacher trainees exposed to think-pair-share pedagogy whereas the mean score obtained for the post-test was 4.30, a mean gain of 2.20 in fovour of the post-test. The null hypothesis that there was no statistically significant difference between the pre-test scores and post-test scores when thinkpair-share learning technique is used was therefore rejected at 0.05 significance level.

\section{Literature Review}

Playing is different from learning and working (Hughes,1999). Playing activity helps to achieve complete development, both physically, intellectual, social, moral, and emotional. Learning activity can be fun if it is done with a game. They differ from non-educational games where the purpose is primarily on entertainment. Educational video games can motivate children and allow them to develop an awareness of consequentiality. Children are allowed to express themselves as individuals while learning and engaging in social issues.

Game-based learning (GBL) is a type of game play that has a defined learning outcome. Generally, gamebased learning is designed to balance subject matter with gameplay and the ability of the player to retain and 
apply the subject matter to the real world. It can be said that playing and learning are synonymous, leading to cognitive and emotional development inside a social and cultural context, for instance, the game of hide and seek. Thus, in such a game, good hiders need visual and spatial perspective to define the best hiding places while seekers must be skilled at searching for cues from the surroundings and choosing the most probable location for the hider among various possible places (Bhoopathi, Sheoran \& Välimäki, 2006).

In classrooms, social game-based learning platforms are increasing in popularity as they purport to enable students to reinforce knowledge and develop social and leadership skills (Green \& Bavelier, 2012). The use of collaborative game-based role-play for learning provides an opportunity for learners to apply acquired knowledge and to experiment and get feedback in the form of consequences or rewards, thus getting the experiences in the "safe virtual world". In a successful game-based learning environment, choosing actions, experiencing consequences, and working toward goals allows players to make mistakes through experimentation in a risk-free environment (Green \& Bavelier, 2012). Games have rules and goals that inspire motivation. Educational games are interactive activities that provide outcomes and feedback. Most games also have problem-solving situations that spark creativity (Kim, Park \& Baek, 2009). One remarkable thing about educational games is that they remove much of the intimidation inherent in the learning process. A good game provides an opportunity to participate not only verbally and visually, but also in a tactile way as well. Educational games offer a unique structure to complement traditional teaching strategies and infuse teaching with energy, spark innovative thinking and provide diversity in teaching methods.

Educational games often act as learning trigger which induce discussion amongst students following game play. As pedagogical devices, games are extremely useful and are effective for dealing with problem solving and key concepts in the teaching and learning of science.

It also encourages collaborative problem-solving skills. Using games provide easy means to incorporate peer learning aid with high concentration levels. For instance, Siegler and Ramani (2008) conducted an experimental study to assess the effectiveness of chutes and ladder game to teach mathematics among school children. The result shows that the students who played game board improved in mathematical numbering than the students who played colour board game.

Another study was done by Lakshmi (2007) to evaluate the effectiveness of snake and ladder game on the level of knowledge regarding common ailments among school children in Bangalore. The result showed that children had adequate knowledge $(75.3 \%)$ in the area of dental carries and moderately adequate knowledge $(42.5 \%)$ in the area of worm infestation. The post-test knowledge score was higher than knowledge score of pre-tests. The estimated ' $\mathrm{t}$ ' value was 19.16 at $\mathrm{p}<0.05$ level. It was concluded that snake and ladder game was an effective method of imparting information to the children regarding common ailments. Castillo (2001) undertook a study to ascertain the impact of snake and ladder game on their knowledge about basic health concepts with Mexican students. They reported a significant improvement of the knowledge of the students who were taught using the snake and ladder game over those who were taught using the traditional method.

Think-pair-share strategy on the other hand, is a new trajectory against the long-lived conventional methods of teaching which judge students' intelligence based on ability to solve problems, utilize logic and think critically. Ruiz-Primo (2011) opined that in addition to the benefits gained through cooperative learning and increased wait time, the aspect of formative assessment that the think-pair-share strategy provides is valuable to the learning process. Using think-pair-share allows the teacher to gain insight into the quality of student understanding. When teachers are able to measure their students' understanding, they can use this information to alter their instruction in a way that would be more beneficial to learners. Informal formative assessment describes the process of teachers gaining new information about student understanding and using that information to immediately shape the instruction in order to better facilitate student learning. Informal formative assessment can occur during student-teacher or student-student interaction that takes place during Think-Pair-Share. These interactions allow teachers the opportunity to observe students' thinking through their explanations and dialogue.

Jebur, Jasim and Jaboori (2012) finds that implementation of this model resulted in higher learning results in a General Physics class. Similarly, Fitzgerald (2013) writes that using think-pair-share led to higher achievement results. Roswati and Radjab (2014) opined that implementing think-pair-share pedagogy enabled their students to become better speakers of the target language in addition to fostering their motivation. McKeachie and Svinicki (2006) stated that following think-pair-share activities, their students often feel more at ease to participate in a general discussion. Besides, Baleghizadeh (2010) argued that when 
his students in the second year of Physics programme worked with think-pair-share pedagogy, their wordbuilding abilities improved greatly.

The Think-Pair-Share learning technique is a versatile and simple technique for improving students' reading comprehension. It gives students time to think about an answer and activates prior knowledge. Think-pairshare learning technique enhances students' oral communication skills as they discuss their ideas with one another. This strategy helps students become active participants in learning and can include writing as a way of organizing thoughts generated from discussions which is in consonant with Sumarsih and Sanjaya (2013) when they said 'applying think-pair-share strategy improved the mean of students' scores in their writing class'.

Think-pair-share learning technique reinforces students' communication skills. Each student takes his/her chance to speak, discuss and participate which has many positive effects on the whole group where students feel more self-confident and more active in the class. Moreover, they learn to listen to each other's point of view and to respect each other's ideas and thoughts. Working in pairs also reduces stress and embarrassment. If they give a wrong answer, for example, they won't feel shy because the embarrassment is shared. Students feel safer and more relaxed when talking in small groups, rather than having to speak in front of the entire class. The Think-pair-share activity gives student the opportunity to feel more comfortable sharing their thoughts and in addition to fostering social skills. Think-pair-share strategy, also improves students' speaking and listening skills. When pairs brainstorm together, each student learns from their partner. This can help students expand their vocabulary as they learn new words from their peers and build on their prior knowledge.

Research within cooperative learning shows that there has been little study conducted on how the use of game-based and think-pair-share pedagogies can improve the performance of teacher trainees in science subject in Colleges of Education in Ghana. This creates a literature gap, hence the current study. This study therefore seeks to examine the impact of game-based and think-pair-share pedagogies on the performance of teacher trainees in science at Enchi College of Education in the Aowin Municipality in the Western North Region of Ghana.

\section{Statement of the Problem}

Poor academic performance of teacher trainees of Colleges of Education in science subjects has been a matter of great concern for tutors and management of Colleges of Education in Ghana and Enchi College of Education in particular. The problem is caused by the use of poor teaching methods by tutors such as talk and chalk method, giving of large amount of lecture notes and students not engaged in practical activities making them passive learners only. Therefore, the study sought to examine the impact game-based and think-pair-share pedagogies on teacher trainees' performance in science at Enchi College of Education in the Aowin Municipality.

\section{Purpose of the Study}

The purpose of this study was to examine the impact of game-based and think-pair-share pedagogies on teacher trainees' performance in science. The study specifically sought to:

1. determine the impact of game-based pedagogy on teacher trainees' performance in science.

2. determine the impact of think-pair-share pedagogy on teacher trainees' performance in science.

\section{Research Questions}

The following research questions were formulated to enable the researcher to gather relevant information for the study:

1. What is the impact of game-based learning approach on the ability of teacher trainees to learn science?

2. What is the impact of think-pair-share pedagogy on the ability of teacher trainees to learn science?

\section{Research Hypotheses}

The research hypotheses to be tested at 0.05 level of significance are: 
1. $\mathrm{H}_{0}$ : There is no significant difference in the post-test and pre-test results of level 100 teacher trainees taught using game-based pedagogy.

2. $\mathrm{H}_{0}$ : There is no significant difference in the post-test and pre-test results of level 100 students taught using think-pair-share pedagogy.

\section{Methodology}

The study sought to examine the impact of game-based and think-pair-share pedagogies on teacher trainees' performance in science. The study was carried out in Enchi College of Education in Aowin Municipality in the Western North Region of Ghana.

The research approach employed for this study is quantitative which focuses on gathering numerical data and generalizing it across groups of people or to explain a particular phenomenon (Babbie, 2010). The researcher adopted action research to carry out the investigation. This research was carried out within the context of the researcher's environment- that is, with the pre-service teachers and at the college in which the tutor works-on questions that deal with educational matters at hand (Alhassan, 2006).

Action research was used in testing hypothesis for the study, that is to determine whether there is significant difference in the post-test and pre-test results of teacher trainees exposed to think-pair-share learning technique. A multi-stage sampling using stratified, simple random and quota sampling technique were used to sample eighty (80) respondents. This was made up of forty (40) male teacher trainees and forty (40) female teacher trainees. The determination of the sample size depended on Best and Kahn's (1995) assertion that there is no fixed number of subjects that determine the size of an adequate sample.

The sampling techniques used included stratified sampling, simple random and systematic sampling. Males and females were considered as a group or stratum. Level 100 male and female students were considered as a group or stratum. Simple random sampling technique was used to determine the starting point on the sample frame. Following this, the students in each group were systematically selected based on their position within the sample frame for both game-based learning approach and think-pair-share learning technique treatment group. This was done by selecting the fourth $\left(4^{\text {th }}\right)$ count starting from a specific point on the sample frame to select 40 male students and 40 female students for the study. These sampling procedures were used because they provide relatively a fairer chance for each respondent to be part of the study. This makes the findings of the study more representative. The instruments used for the data collection was test. Two forms of the achievement test consisting of ten (10) item each of pre-test and post-test was used for the study.

In order to ensure the validity of the tests for collection of data, three colleague tutors from the science department scrutinized the test items for its ambiguity. The suggestions offered were used for improvement of the instruments. This helped to improve the validity of the instrument. The research instrument was then pilot-tested with 20 teacher trainees from Wiawso College of Education in the Western North Region of Ghana. This is because the college was a co-educational institution and offered the same programmes as the actual study center. The purpose of the pilot testing was to determine the reliability of the research instruments. The Spearman-Brown split-half reliability(r) analysis using SPSS version 21.0 was adopted to test the reliability of the instrument. The Spearman-Brown split-half reliability(r) analysis yielded coefficients of 0.81 . According to Dörnyei and Taguchi (2010), a reliability coefficient ( $\mathrm{r}$ ) of 0.70 is deemed as an acceptable measure of reliability because more than 0.70 the threshold value of acceptability is achieved as a measure of reliability. This means that the instrument was deemed appropriate for data collection. Protection of participants and their responses were assured by obtaining informed consent, protecting privacy and ensuring confidentiality. In doing this, description of the study, the purpose and the possible benefits were mentioned to participants.

The data collected on both game-based and think-pair-share pedagogies treatment groups by the researcher through the pre-test and post-test were fed into SPSS version 21.0 and analysed using paired t-test. The data analysis was guided by the research questions for the study. T-test was used to compare the post-test and pre-test scores of both game-based and think-pair-share pedagogies treatment groups.

\section{Pre-intervention}

Prior to the implementation, a pre-test was applied to the two groups to determine their equivalence. Thus, their pre-test scores were determined before they were given their treatments. Thus forty (40) level 100 
participants made up of twenty (20) males and twenty (20) females were subjected to game-based pedagogy and another forty (40) level 100 participants made up of twenty (20) males and twenty females (20) were also subjected to think-pair-share pedagogy. This enabled the researcher to compare the performance of the two groups before and after the treatments were given.

\section{Intervention}

The intervention of the study lasted for four weeks with a three-hour lesson per week. Educational educative card game was used to teach the participants who were grouped under game-based learning approach group. When designing the games, particular attention was paid to the Integrated Science Course objectives and the appropriateness of the game to the students' level. The rules of the game were explained and made available to students. on the table of each group.

Rules on how to play

1. Identify a mixture that has been placed on the table.

2. Select a card that identify that type of mixture

3. If the student is able to card that identifies the type of that mixture, the card is kept.

To use the educative game to reinforce the students' understanding on mixture, statement like I dissolve substance I came into contact to form solution, who am I? and their corresponding responses were prepared on a set of cards and students were made to pick a statement and its corresponding response when playing the game. The students were supervised as they played the game and the person with the most complete matched pairs is declared as a winner.

The think-pair-share technique was used to teach the participants who were grouped under think-pair-share pedagogy. During this process, questions were posed to participants to excite their thinking to search for a solution. The participants were asked to think alone to resolve the issue or problem at hand within a given time frame. The participants were then asked to split up into pairs and discuss what they thought about the problem posed to them to share, exchange views and ideas to reach a common answer. Each pair then joined another paired group to share, exchange views and ideas to reach a common answer till all the participants had interacted with each other.

\section{Post-intervention}

After the treatment, a post-test was conducted for both groups. The achievement test, which was previously administered as pre-test, was re-administered as post-test to both game-based and think-pair-share pedagogy treatment groups under the same conditions. This also helped the researcher to determine whether there is a significance difference between the post-test scores of the treatment groups.

\section{Results and Discussions}

The study sought to examine impact of game-based and think-pair-share pedagogies on the ability of teacher trainees to learn science. The research question and its corresponding hypotheses below was set to help gather the relevant data.

\section{Research Question 1: What is the impact of game-based pedagogy on the ability of teacher trainees to learn science?}

In other to answer research question one, the following null and alternate hypotheses were set and used.

\section{Hypotheses \# 1}

$\mathrm{H}_{0}$ : There is no significant difference in the post-test and pre-test results of level 100 teacher trainees taught using game-based pedagogy.

$\mathrm{H}_{1}$ : There is significant difference in the post-test and pre-test results of level 100 teacher trainees taught using game-based pedagogy.

Table 1 presents paired t-test result for game-based pedagogy. 
Table 1: Results of paired t-test for game-based pedagogy

\begin{tabular}{|l|l|c|l|l|l|l|}
\hline & N & Mean & $\begin{array}{l}\text { Mean } \\
\text { Dif }\end{array}$ & Df & t-stat & $\begin{array}{c}\text { sig.(2- } \\
\text { tailed) }\end{array}$ \\
\hline Pre-test & 40 & 2.58 & & & & \\
\hline Post-test & 40 & 6.83 & 4.25 & 39 & 14.984 & 0.000 \\
\hline
\end{tabular}

From Table 1, it can be elicited that the mean score during the pre-test was 2.58 whereas the mean score during the post-test was 6.83 . This represents a mean gain of 4.25 in favour of the post-test. This means that the performance of the students before the use of the game-based learning was below average. However, after the post-test, the performance can be described to be above average. A comparison of the pre-test and post-test yielded a significant value of 0.000 . Since the significant value of 0.000 is less than the alpha level of 0.05 , then it can be concluded that the difference between the pre-test scores and post-test scores was statistically significant. The null hypothesis that there was no statistically significant difference between the pre-test scores and post-test scores when game-based learning is used was therefore rejected at 0.05 significance level (t-14.984, 39).

This confirms the findings of Siegler and Ramani (2008) who conducted an experimental study to assess the effectiveness of chutes and ladder game to teach mathematics among school children and reported that the students who played game board improved in mathematical numbering than the students who played colour board game. It is also in tandem with the findings of Lakshmi (2007) who evaluated the effectiveness of snake and ladder game on the level of knowledge regarding common ailments among school children in Bangalore and concluded that snake and ladder game was an effective method of imparting information to the children regarding common ailments. The findings of the study do not deviate from the findings of Castillo (2001) who reported a significant improvement of the knowledge of the students who were taught using the snake and ladder game over those who were taught using the traditional method. In effect, gamebased pedagogy is an effective technique that can be used to improve the performance of teacher trainees especially in science.

Research Question 2: What is the impact of think-pair-share pedagogy on the ability of teacher trainees to learn science?

To help answer this question, the following null and alternate hypotheses were used.

\section{Hypotheses \# 2}

$\mathrm{H}_{0}$ : There is no significant difference in the post-test and pre-test results of level 100 students taught using think-pair-share pedagogy.

$\mathrm{H}_{1}$ : There is a significant difference in the post-test and pre-test results of level 100 students taught using think-pair-share pedagogy.

Table 2 presents the paired t-test results for think-pair-share learning technique.

Table 2: Results of paired t-test for think-pair-share pedagogy

\begin{tabular}{|l|l|c|c|c|c|c|}
\hline & $\mathbf{N}$ & Mean & $\begin{array}{c}\text { Mean } \\
\text { Dif }\end{array}$ & Df & t-stat & $\begin{array}{c}\text { sig.(2- } \\
\text { tailed) }\end{array}$ \\
\hline Pre-test & 40 & 2.10 & & & & \\
\hline Post-test & 40 & 4.30 & 2.20 & 39 & 10.506 & 0.000 \\
\hline
\end{tabular}

Results from Table 2 show that, out of a possible 10 points, the mean score during the pre-test was 2.10. This represents a below average performance. During the post-test the mean score went up to 4.30. Comparing the pre-test score and post-test score, it can be observed that performance after the use of the think-pair-share more than doubled the performance of the students during the pre-test. From Table 2, a comparison of the pre-test and post-test yielded a sig value of 0.000 . Since the sig. value of 0.000 is less than the alpha level of 0.05 , then it can be concluded that the difference between the pre-test scores and post-test scores was statistically significant.

The null hypothesis that there was no statistically significant difference between the pre-test scores and posttest scores when think-pair-share learning technique is used was therefore rejected at 0.05 significance level 
$(\mathrm{t}=10.506,39)$. This finding is in line with the findings of Jebur, Jasim and Jaboori (2012) who postulated that the implementation of think-pair-share model resulted in higher learning results in a General Physics class. Similarly, it confirms the findings of Fitzgerald (2013) who argued that using think-pair-share led to higher achievement results.

\section{Findings}

Based on the results and the discussions presented in relation to the hypothesis and research questions, the following are the major findings. It was realized from the testing of hypothesis that the mean score of 2.58 was obtained from the pre-test for teacher trainees exposed to game-based pedagogy whereas the mean score obtained for the post-test was 6.83 , a mean gain of 4.25 in favour of the post-test. A comparison of the pretest and post-test yielded a significant value of 0.000 which is less than the alpha level of 0.05 , an indication that the difference between the pre-test scores and post-test scores was statistically significant. The null hypothesis that there was no statistically significant difference between the pre-test scores and post-test scores when game-based pedagogy is used was therefore rejected at 0.05 significance level $(\mathrm{t}-14.984,39)$.

It was again revealed that, the mean score of 2.10 was obtained from the pre-test for teacher trainees exposed to think-pair-share pedagogy whereas the mean score obtained for the post-test was 4.30, a mean gain of 2.20 in fovour of the post-test. Comparison of the pre-test and post-test yielded a significant value of 0.000 , which is less than the alpha level of 0.05 , indicates that the difference between the pre-test scores and post-test scores was statistically significant. The null hypothesis that there was no statistically significant difference between the pre-test scores and post-test scores when think-pair-share learning technique is used was therefore rejected at 0.05 significance level $(t=10.506,39)$.

\section{Conclusion and recommendation}

From the results and the discussions presented, it can be concluded that there is some level of improvement on the performance of teacher trainees in science when game-based pedagogy and think-pair-share pedagogy were adopted to teach science lessons.

Based on the conclusions of the study, for effective teaching, learning and assessment of science, creative approaches such as game-based pedagogy and think-pair-share pedagogy should be adopted by science tutors in Enchi College of Education for effective teaching and learning since game-based pedagogy and think-pair-share pedagogy enhance the ability of teacher trainees to learn science.

\section{References}

1. Alhassan, S. (2006). Modern approaches to research administration for research students. Amakom-Kumasi: Payless Publication. .

2. Babbie, E. R. (2010). The practice of social research (12 ${ }^{\text {th }}$ ed.). Belmont, CA: Wadsworth Cengage.

3. Baleghizadeh, S. (2010). The effect of pair work on a word-building task. Elt Journal, 64(4), 405413.

4. Best, K., \& Khan, S. (2005). Real world research. Oxford: Blackwell.

5. Bhoopathi, P., Sheoran, R., \& Välimäki, M. (2006). Educational games for mental health professionals. Cochrane Database of Systematic Reviews, 2(2), 23-33.

6. Castillo, E. (2001). Maximizing serendipity in fair-division algorithms: The maximal serendipity method. (Doctoral dissertation), St. Mary's University of San Antonio, Texas).

7. Dörnyei, Z., \& Taguchi, T. (2010). Questionnaires in second language research: Construction, administration, and processing (2nd ed.). Mahwah, NJ: Lawrence Erlbaum Associates.

8. Fitzgerald, D. (2013). Employing think-pair-share in associate degree nursing curriculum. Teaching and Learning in Nursing, 8(3), 88-90.

9. Green, C. S., \& Bavelier, D. (2012). Learning, attentional control, and action video games. Current Biology, 22(6), R197-R206.

10. Hughes, J. (1999). Altered states: Creativity under the influence. New York: Watson-Guptill Publications.

11. Ismail, S. (2006). Political life in Cairo's new quarters: Encountering the everyday state. Minneapolis: University of Minnesota Press. 
12. Jebur, M. S., Jasim, H. H., \& Jaboori, H. R. (2012). The effect of using think-pair-share technique on EFL students' achievement in the course of general English. Journal of College of Basic Education, 15(80), 823-838.

13. Kim, B., Park, H., \& Baek, Y. (2009). Not just for fun, but serious strategies: Using meta-cognitive strategies in game-based learning. Computers and Education, 52, 800-810.

14. Lakshmi, H. (2007). Translation studies: Theory and practice. Hyderabad: Booklinks Corp.

15. McKeachie, W. J., \& Svinicki, M. (2006). McKeachie's teaching tips: Strategies, research and theory for college and university teachers (12th ed.). New York: Houghton Mifflin.

16. Roswati, Z. M., \& Radjab, D. (2014). Improving students' speaking skill by using think-pair-share strategy at the second semester of Syariah Class A at language center of UinSuska Riau. English Language Teaching, 2(1), 1-12.

17. Ruiz-Primo, M. (2011). Informal formative assessment: the role of instructional dialogues in assessing students' learning. Studies in Educational Evaluation, 37(1), 15-24.

18. Siegler, R. S., \& Ramani, G. B. (2008). Playing linear numerical board games promotes low-income children's numerical development. Developmental Science, 11(5), 655-661.

19. Sumarsih, M., P. \& Sanjaya, D. (2013). TPS as an effective technique to enhance the students' achievement on writing descriptive text. English Language Teaching, 6(12), 106-113.

20. Utama, I. P., Marhaeni, A., \& Putra, I. N. (2013). The effect of think pair share teaching strategy to students' self-confidence and speaking competency of the Second Grade Students of SMPN 6. SINGARAJA e-Journal of Postgraduate Program, University of Education, Ganesha, English Study Program of Education, 1, 1-10. 